\title{
Pub securitisation: What next?
}

Received (in revised form): 19 August 2003

\section{Michael Cox}

is an associate director in the whole business securitisation team at Fitch Ratings and his primary area of expertise is the UK pub securitisation sector. Michael was lead analyst on the recent Pubmaster, Unique and Spirit transactions, and has responsibility for monitoring the performance of other pub securitisations.

\section{Abstract}

If you had a drink in your local pub last night, there is a four to one chance that you were doing so in one financed by securitisation. This time next year, the odds are likely to have shortened to three to one. This paper gives an introduction to the basic concept of pub securitisation and an overview of the market, and considers whether managed pubs are likely to be financed using this technique. The paper is written by an analyst whose business is to analyse and size debt in complex structured transactions. It therefore has some technical sections and deals with issues of credit risk as well as addressing the basics.

\section{Keywords:}

pubs, securitisation, structured finance, credit, credit ratings, whole business securitisation

\section{SUMMARY}

Pub securitisation is now just over five years old, but has already been used to finance 25 per cent of the pubs in the UK in eight separate transactions. This technique enables pub companies to raise greater debt than most other methods, in return for strict operational controls and a tight security package that offer investors greater protection than traditional financing. Recent months have seen Mitchells \& Butlers announce its intention to raise debt through a whole business securitisation this autumn, and Scottish \& Newcastle entering the process of disposing of its remaining pubs, with bidders considering securitisation as a potential means of financing. The leverage achieved by the one securitisation of managed pubs so far was seen by some as being relatively low, and some commentators have argued that this is not a good technique for financing this type of estate. The difference in leverage achieved between leased pub securitisation and managed pub securitisation can be justified by the higher volatility, both

as sale and leaseback and bank debt have advantages and disadvantages over securitisation, but the overall leverage obtained is likely to be lower than securitisation as the protections for 


\section{Whole business securitisation}

\author{
Historic issuance
}

investors are fewer. The existing transactions will continue to raise more debt to finance acquisitions, and to refinance themselves, but new leased pub transactions are likely to be rare. Further managed pub securitisation should be seen through Mitchells \& Butlers in the autumn, and it is likely that at least some of Scottish \& Newcastle's disposed pubs will be financed using the technique.

\section{INTRODUCTION TO PUB SECURITISATION}

For those unfamiliar with the concept of pub securitisation, it is appropriate to describe briefly the history and the mechanics. Whole business securitisation is a niche area of structured finance, responsible for only a handful of transactions each year, of which pub securitisations form a very significant number. This technique enables a company to raise highly rated long-term debt in return for signing up to significant operational restrictions. It has been applied to finance companies owning nursing homes, hospitals, ferries, theatres, theme parks, motorway service areas and ports. Other rumoured transactions that have not (yet) been to market include cinemas, holiday parks and cable television companies. There are limits and many hurdles, but a company that generates cash, owns tangible, valuable assets and operates in a mature, stable market with high barriers to entry is likely to be a good candidate for whole business securitisation. Pub companies ('pubcos') are the classic example.

\section{History}

While there are eight pub securitisations (all rated by the author's company), there have been a total of 15 issues (Figure 1), with five pubcos 'tapping' their structures (adding more pubs and raising more debt). First to embrace the pub securitisation market was Wellington Pub Company, which closed in February 1998. This was closely followed by Punch Taverns Finance the next month, and the subsequent year saw three transactions issue $£ 1.3 \mathrm{bn}$. There were four issues in 2000, raising nearly $£ 2$ bn, including the massive Punch Funding II, which included both leased and managed pubs and was the first pub transaction to be insured by a monoline insurer. In contrast, 2001 was a quiet year, with two taps worth $£ 370 \mathrm{~m}$. This was followed by issuance of more than $£ 2 \mathrm{bn}$ in 2002 , from three transactions. 2003 has already seen Spirit raise a further $£ 130 \mathrm{~m}$, and a transaction announced by Mitchells \& Butlers, which owns over 2,000 of the best pubs in the country, is eagerly awaited by the market.

\section{Mechanics}

Whole business securitisation, and therefore pub securitisation, usually uses a secured loan structure whereby a loan is advanced by a special-purpose vehicle (the 'issuer') to a pubco, or 'borrower'. The loan is secured on substantially all the assets of the pubco, using fixed charges where possible, and an all-encompassing floating 


\begin{tabular}{|c|c|}
\hline February 1998 & $\begin{array}{c}\text { Wellington Original } \\
£ 231 \mathrm{~m}\end{array}$ \\
\hline March 1998 & $\begin{array}{c}\text { Punch Taverns Original } \\
£ 535 \mathrm{~m}\end{array}$ \\
\hline March 1999 & $\begin{array}{c}\text { Unique Original } \\
£ 810 \mathrm{~m}\end{array}$ \\
\hline June 1999 & $\begin{array}{c}\text { Pubmaster Original } \\
£ 305 \mathrm{~m}\end{array}$ \\
\hline September 1999 & $\begin{array}{c}\text { Alehouse Original } \\
£ 183 \mathrm{~m} \\
\end{array}$ \\
\hline February 2000 & $\begin{array}{c}\text { Pubmaster First Tap } \\
£ 109 \mathrm{~m} \\
\end{array}$ \\
\hline February 2000 & $\begin{array}{c}\text { Avebury Original } \\
£ 134 \mathrm{~m} \\
\end{array}$ \\
\hline June 2000 & $\begin{array}{c}\text { Punch Funding II Original } \\
£ 1,484 \mathrm{~m}\end{array}$ \\
\hline October 2000 & $\begin{array}{c}\text { Punch Taverns Tap } \\
£ 250 \mathrm{~m}\end{array}$ \\
\hline February 2001 & $\begin{array}{c}\text { Unique First Tap } \\
£ 335 \mathrm{~m} \\
\end{array}$ \\
\hline August 2001 & $\begin{array}{c}\text { Alehouse Tap } \\
£ 34.5 \mathrm{~m} \\
\end{array}$ \\
\hline April 2002 & $\begin{array}{c}\text { Spirit Original } \\
£ 656.5 \mathrm{~m} \\
\end{array}$ \\
\hline September 2002 & $\begin{array}{c}\text { Unique Second Tap } \\
£ 855 \mathrm{~m}\end{array}$ \\
\hline November 2002 & $\begin{array}{c}\text { Pubmaster Second Tap } \\
£ 535 \mathrm{~m} \\
\end{array}$ \\
\hline August 2003 & $\begin{array}{l}\text { Spirit First Tap } \\
£ 132.5 \mathrm{~m}\end{array}$ \\
\hline
\end{tabular}

Figure 1: Pub sector issuance timeline

charge. The issuer issues notes secured on the loan in the capital markets. The pubco agrees to certain restrictions on the way it operates its business to de-risk the operations as much as possible, enabling debt raised to reach the highest possible rating. A typical structure is illustrated in Figure 2.

In Figure 2, Pubco owns and operates the pubs. The issuer is a new vehicle, restricted from other activities through a series of covenants. The issuer issues the notes, which are sold to investors such as pension funds and insurance companies. The cash it raises 


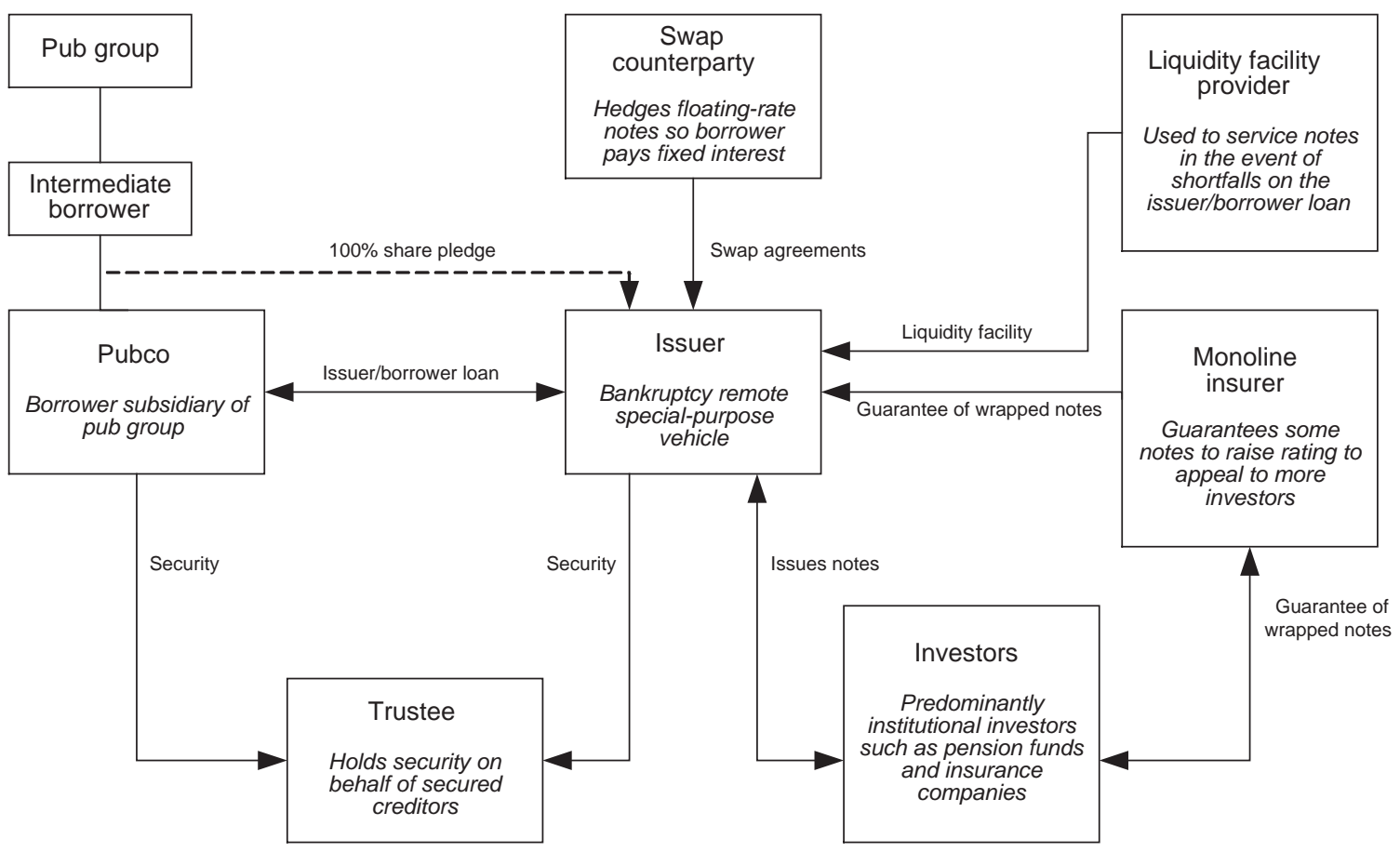

Figure 2: Pub securitisation structure

\section{Protection on insolvency}

is loaned to Pubco, and the proceeds are usually used to repay some form of bridge financing. Pubco grants security over its assets to the trustee, as does the issuer, and Pubco's parent also pledges its shares in Pubco. The issuer enters into a swap agreement with the swap counterparty to hedge the floating-rate notes, such that the interest obligations of the borrower are fixed. A liquidity facility is arranged on day one, so that in the event of shortfalls in cash flow from the loan the issuer can meet its obligations under the notes. Often a monoline insurer will act to insure some notes, so that they can be rated higher and therefore sold more easily.

The pubco operates subject to a financial covenant, usually set such that earnings before interest, taxation, depreciation and amortisation (EBITDA) must be at least 1.25 times debt service, which if breached enables the issuer to appoint an administrative receiver over the pubco. The administrative receiver should then continue to operate the company to the benefit of the issuer (and therefore the noteholders). In the event of a downturn, such that the pubco cannot afford to make the repayments on the loan, amounts are drawn under the liquidity facility so that timely payments are still made on the notes. While the structure primarily envisages the continuation of the business, it also allows for the disposal of the business if that is considered more appropriate at the time.

By ensuring that available cash is paid in strict priority to senior noteholders before junior noteholders, and reducing the ability of junior noteholders to enforce against the issuer, the notes issued by 


\section{Operational covenant package}

\section{Dividend restrictions}

the issuer can be issued at different rating levels, usually ' $A$ ' and 'BBB', and often 'BB' as well. This reduces the weighted average cost of debt by carving out less risky, more highly rated and therefore cheaper debt. The interest rate on the notes is fixed either through swaps or by raising fixed-rate debt. The notes are always fully amortising, and the transactions usually amortise the most highly rated debt first.

The pubco is restricted by a series of operational covenants to reduce the risks associated with the business. The restrictions include disposals of properties to prevent sales of the business assets, but also to reduce the speed with which the nature of the business can change over time. The use to which cash from disposals can be put is also restricted to acquisitions or repayment of debt. Acquisitions are usually restricted to businesses in the same area, and the amount the company can pay for a given pub is usually restricted by a yield test. Other structural features may include a senior maintenance capital expenditure reserve, restrictions on development capital expenditure and a cash reserve fund.

The structure also restricts the ability for cash that would otherwise be available for debt service to leave the structure. Hence the pubco's ability to pay dividends, or make any other payment to other group companies, such as loans or repayment of loans, is restricted. Above a particular debt service coverage ratio (DSCR), the company is free to pay dividends (although they are often limited to a given amount). If the DSCR falls below that level, however, all surplus cash is trapped in the pubco, often in an account subject to a fixed charge, thereby building up a significant cash balance to protect against default. By putting such a structure around the funding of the pubco, the debt raised is at higher rating levels, and higher leverage, than would be the case for a corporate bond where normally a single tranche of debt at a single rating is issued.

\section{Process}

The process of undertaking a pub securitisation, or indeed any whole business securitisation, is lengthy and costly, and is rarely attempted where the proceeds are likely to be less than $£ 100 \mathrm{~m}$. There will be many parties, with the working parties list stretching well over 100, including at least one investment bank, several sets of lawyers, a valuer, two or three rating agencies, a trustee and potentially a monoline insurer. Fees will vary between 1 per cent and 3 per cent of the debt raised, with some elements fixed and many dependent upon the amount raised. Transactions take a long time to arrange, and the author's company can work on a transaction for anything between six and 12 months from start to close, but the lead manager and company will often start work many months earlier than that. 


\section{MARKET UPDATE}

Activity in the UK pub securitisation sector continues at a furious pace. Last year Punch Group demerged its leased and managed businesses, separating the collateral acting as security for Punch Funding II and redeeming a large proportion of the debt. The managed arm, which was renamed Spirit Group, launched its own securitisation, Spirit Funding. The leased arm, renamed Punch Taverns, successfully floated, making history by becoming the first pubco to be funded through both public equity and a whole business securitisation. Nomura exited mass pub ownership by selling the Inn Partnership estate to Pubmaster, and the Unique and Voyager estates to a consortium that includes Enterprise Inns. Inn Partnership was tapped into Pubmaster Finance in November, and the Voyager estate took the number of pubs acting as collateral for Unique Pub Finance Company to over 4,000 when it was added in September.

In April this year, Mitchells \& Butlers was demerged from Six Continents' hotels business (renamed Intercontinental Hotels), and shortly afterwards announced a securitisation programme to refinance existing bank debt and return cash to shareholders. The transaction is expected soon, and would involve over 2,000 pubs forming the cream of the original Bass and Allied Domecq estates, and the Scream, Sizzling Pub Company, Toby Carvery, Vintage Inns and All Bar One brands. Scottish \& Newcastle scrapped earlier plans for a sale and manage-back of some of its pubs (which probably would have been securitised), and decided instead to divest its entire retail division, comprising 1,400 high-quality managed pubs including the Chef \& Brewer, John Barras and T\&J Bernard brands, and 130 lodges under the Premier Lodge brand. The buyer will at least consider securitisation as a financing mechanism. Part of the attraction is minimising the equity invested. Even in the event of the group being split up, many of its constituent parts are likely to end up being securitised. Successful issues for Mitchells \& Butlers and Scottish \& Newcastle Retail could see the $£ 5.4 \mathrm{bn}$ of pub funds in the marketplace increase to nearer $£ 10$ bn.

Enterprise Inns, the largest leased pubco, has announced its intention to exercise an option to acquire the Unique and Voyager estates next year, and many practitioners will be hoping that Enterprise converts from traditional financing to the securitisation techniques favoured by its target. Historically Enterprise has dismissed securitisation, but at some point may have to switch from generating shareholder value through acquisitions to other means, which may include using securitisation to increase its leverage and hence its return on equity capital. It remains to be seen whether its 5,300 pubs are swallowed up by Unique's securitisation structure, but, encouragingly, Punch Taverns appears to have achieved a successful balance between the obligations of a FTSE-250 listed plc and a securitised pubco. 


\section{Capital expenditure}

\section{Valuations}

\section{MANAGED PUBS: WILL VOLUME FOLLOW LEASED PUBS?}

The majority of the transactions undertaken so far have been leased pub securitisations (by which is meant leased and tenanted), with the exception of Spirit Funding and its predecessor, joint leased and managed Punch Funding II, standing out among the crowd.

Managed pubs (where the pubco runs the pubs, incurring all the cost but receiving all the revenue) were seen as harder to securitise than leased pubs (where a large part of the revenue is derived in a more stable rental income stream). The success of Spirit, co-led by the then Schroders Salomon Smith Barney (now Citigroup) and Goldman Sachs alliance, combined with the corporate activity of the big managed house players, Mitchells \& Butlers and Scottish \& Newcastle, has led to massive interest in managed pubs among securitisation professionals. But the investment grade debt (being debt rated at 'BBB' up to 'AAA') raised through Spirit relative to the value of the estate (around 60 per cent, compared to 80 per cent for a typical leased estate) has led some commentators to consider other financing options against securitisation with its relatively restrictive operating covenants.

\section{Leverage}

First, it is necessary to consider what is the difference in leverage. A very basic comparison between managed house and leased operator securitisations can be made by looking at EBITDA multiples. Commentators will quote 7.5-8.0 times EBITDA at investment grade for a leased pub securitisation versus only around 6.0 times EBITDA for a managed pub securitisation (the only benchmark being Spirit). This, however, ignores the higher capital expenditure (capex) requirements in managed versus leased pubcos (where frequently tenants are on fully repairing and insuring leases). For example, a managed pubco that generates EBITDA of $£ 100 \mathrm{~m}$ may spend around $£ 15 \mathrm{~m}$ in maintaining its assets in their current state; in contrast a similar leased pubco may spend only $£ 1 \mathrm{~m}$ since most of its tenants are responsible for their own capex. EBITDA multiples of 6.0 times for a managed pubco and 7.5 times for a leased pubco would then represent free cash flow multiples of 7.1 times and 7.6 times respectively. The difference is therefore not as great as first thought, and given that the EBITDA of a leased pubco should not fluctuate as much as that of a managed pubco in the short term, this difference is justified.

Comparisons based on loan-to-value ratios require careful consideration. Valuations are inherently based on what the market will pay for the portfolio, which in turn is based on how little equity needs to be used, ie how much debt can be raised. This circular reference means that measures of leverage against the valuation are not necessarily appropriate, since the two are highly correlated and a significant rise in interest rates could mean values plummet and over-collateralisation disappears. The value has only a small part to play in determining what level of debt is appropriate. 


\section{Operational gearing}

\section{Exposure to tenants}

\section{Volatility}

Among the transactions undertaken so far, at one extreme is Wellington, a free-of-tie leased estate, where the pubco owns the freehold and leases the pub to a lessee, collecting rent and paying an outside servicer to undertake most of the corporate functions. The operational gearing of the pubs lies with the lessee and Wellington benefits from a relatively stable short-term revenue stream. At the other extreme is Spirit's estate of managed pubs, where the pubs are owned and operated by the pubco itself and the income is therefore more volatile, given that all of the operating risk of the pub is borne by Spirit. In between are the other pub securitisations by pubcos, operating a tied-leased or tenanted model, where the pubco leases the pub to a lessee or tenant for below market rent, but forces the retailer to purchase beer and some other drinks from the pubco through the use of a tie. The pubco derives a margin from the sale of the beer, selling above market price to the retailer and using its larger buying power to obtain larger discounts from the brewers. Often the income from gaming machines in the pubs is also shared between the retailer and the pubco. In this way, the operating risk is shared between the pubco and the tenant, with shorter-term tenancies likely to have lower rents and higher beer prices than longer-term leases.

The basic arguments in favour of higher leverage for leased pubcos relate to how volatile the revenue stream is. The argument is that free-of-tie estates are not exposed to the underlying performance of the pub, as the pubco receives only rent; tied estates benefit from having anywhere between 30 and 60 per cent of their income stream coming from regular fixed rent payments; while managed estates bear all the risk of trading, and carry a high fixed cost base. However, there are many more factors that need to be considered.

Of course, while in the short term it is possible for tenants to take the pain of difficult trading conditions, there is only so much they will be able to bear. While the headline figure is that the retailer takes around 50 per cent of the operating profit of the pub, this is before making an allowance for a reasonable salary. In the extreme example of a free-of-tie estate, a 25 per cent fall in the profitability of the pub may result in a 50 per cent cut in the tenant's income. In practice, it is unlikely that the tenant will be able to bear even a 15 per cent fall in the profitability of the pub without thinking hard about whether it is really worth continuing to operate the pub. Tenants can walk away at the end of the lease, or default in the meantime, leaving the pubco forced to reduce rents to attract an alternative operator. Even where rent reviews are upward only, if a pub is suffering through no fault of the retailer, the pubco will reduce rent to keep that good retailer in its pub rather than risk a default and a difficult reletting process that will inevitably result in lower rent anyway.

Hence, in the long run, leased pubcos are exposed to the overall 
Impact of beer
decline

Impact of regulation performance of the pub sector and the general economic environment in the same way as managed pubcos. The difference is that leased pubcos are not exposed to the top slice of the income from the pub (the 'tenant premium', being the difference between the required minimum amount to remain operating the pub and its current trading position).

\section{Long-term revenue streams}

One approach to analysing these transactions considers the longterm sustainability of the pubcos' revenues, and the types of revenue stream. In an environment where barrelage is declining, being offset to an extent by growth in food and in other drinks such as premium packaged spirits and wine, it is important to note that many leased pubcos do not tie these products directly. While the scope of the tie is gradually altered on renegotiations and renewals, many of the pubcos only tie a declining revenue stream in beer. Increases in the revenues of the pub due to additional sales of untied drink products and food can only be captured at rent reviews, and then only if the trading information is available many tenants do not produce reliable, audited accounts. In contrast, managed pubcos will benefit immediately, no matter what the pub is used for, whether for food, wine, beer or even table dancing. In the long term, there is an argument that the managed pubco model will be in a better position to adapt to the changes occurring in the sector.

\section{Cost structures}

Although managed houses may be better at capturing the revenues of the pub going forward, they are more exposed on the lower portion of the profit and loss account. Individual retailers do not have to comply with the Working Time Directive, in contrast to the managers of managed houses (although there is presently an optout), and they are probably able to get maintenance and repairs undertaken more cost effectively. Managed pubcos are particularly exposed to rises in the national minimum wage, with roughly onethird of their weekly paid staff being paid at this level.

\section{Property assets}

In general, the pubs that remain managed rather than leased are the cream of the estates of national brewers. They are the pubs most suited to pub use, and least exposed to long-term changes in the industry. In contrast, many of the leased estates contain at least some smaller pubs in secondary locations that are less certain to be part of the industry if it does go into decline. If beer drinking declines, but is offset by an increase in food revenue in the industry in general, many leased pubs do not have the space in which to fit, the customer base to justify or the cash to spend on a suitable kitchen. 


\section{ALTERNATIVES TO SECURITISATION}

Whether securitisation provides the answer to financing managed pubcos will depend largely on the relative benefits and drawbacks of the alternatives. Pubcos that have low operational leverage (ie that own freeholds) could be financed by equity, although shareholders would have to accept relatively low returns on their investments, and until recently the sector has underperformed the market. The stable cash flow supported by property values means they are probably best suited to a debt-based financing.

\section{Sale and leaseback}

\section{Sale and manage-back}

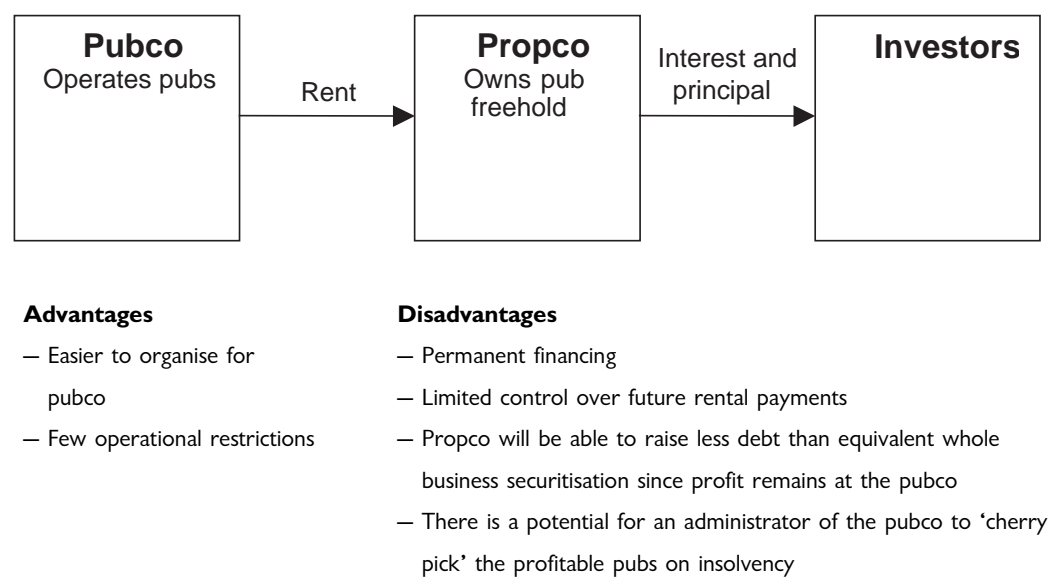

Figure 3: Sale and leaseback

A sale and leaseback (Figure 3) was used by Laurel in December 2002, when it sold the freeholds of 280 pubs to a property company and leased them back, raising $£ 318 \mathrm{~m}$. The property company can seek a number of different sources of financing, including securitisation. Securitising the property company interest in sale and leasebacks results in lower proceeds than the equivalent whole business securitisation, however, because security is not taken over the operating company itself as well as the assets; this is therefore viewed as less robust on an insolvency.

Small-scale sale and leasebacks by both individuals and managed pubcos operating a few pubs are increasingly popular, with leased pubcos often acquiring freeholds from operators who lease them back. The freehold interest will then often be securitised itself.

A further variation on this theme is the sale and manage-back (Figure 4), as proposed by Scottish \& Newcastle but rejected in favour of a true disposal. A portion of Scottish \& Newcastle's managed pubs would have been sold, but then managed by Scottish $\&$ Newcastle under an operating contract that would have rewarded Scottish \& Newcastle on performance and, crucially in this case, offered a continued outlet for Scottish Courage products. This is common in the hotel sector, but would have represented a first (at 


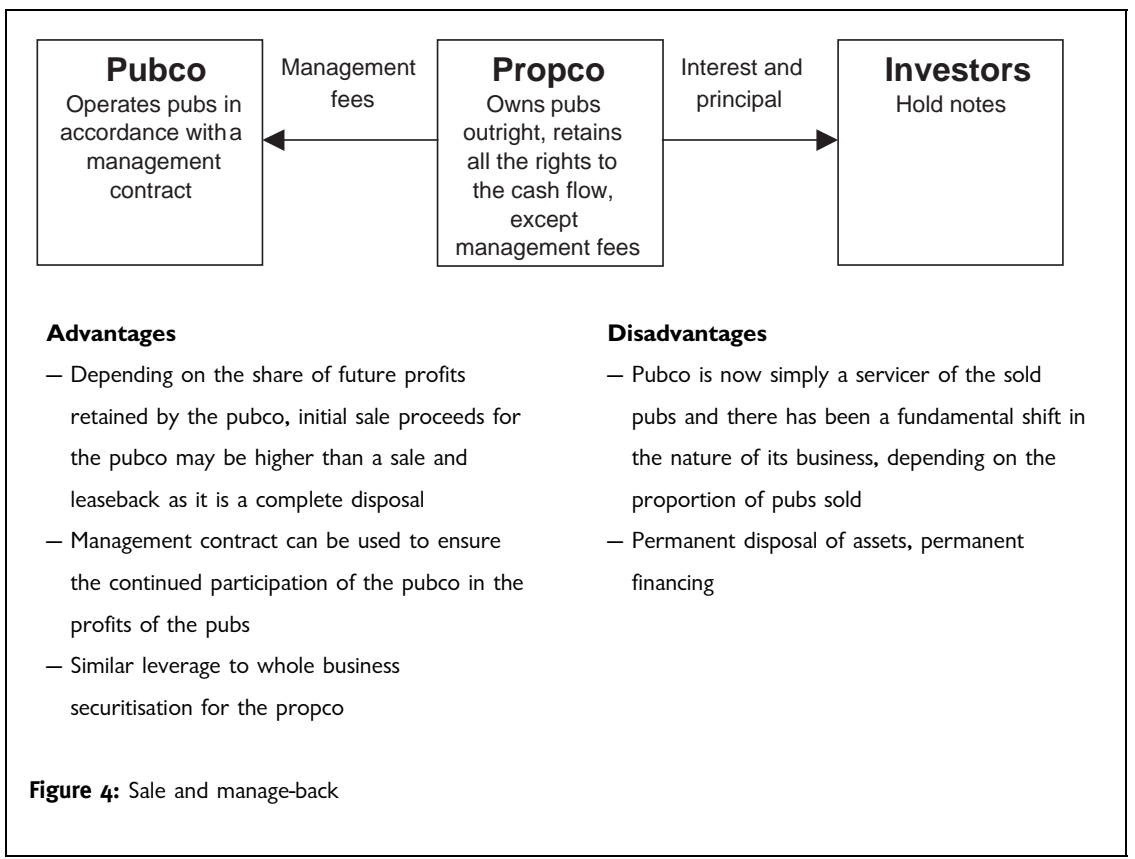

least on this scale) for managed pubs. Scottish \& Newcastle ditched the proposal apparently in favour of an outright sale of the entire division as it felt this would be the best way to achieve full value.

Of course, whether the sale and leaseback and sale and manageback options are attractive will largely depend upon the availability of finance for this type of transaction. Rating agencies and banks are wise to attempts to arbitrage different structures, such that the drawbacks of the property company's interest in a sale and leaseback - such as uncertainty on an insolvency of the operator, fewer operational restrictions and the lack of spare cash to trap on a downturn - will be recognised, and leverage reduced accordingly. Equally, the drawbacks of a sale and manage-back structure, such as cash leakage to the manager and uncertainty on manager insolvency, will be recognised.

\section{Bank loan}




\section{Impact of change in insolvency law}

Bank debt (Figure 5) is becoming increasingly competitive as many banks are keen to enter the sector, often providing a bridge loan for which a securitisation is the 'take-out' option, but also providing more permanent financing.

\section{IMPLICATIONS OF FORTHCOMING LEGISLATION}

The Enterprise Act 2002 included changes in insolvency law that came into effect on 15 September 2003. The abolition of the ability to appoint an administrative receiver where the floating charge was granted after the implementation of these aspects of the legislation may have an effect on financing methods. There is a capital markets exemption which means that securitisations will continue to retain the ability to appoint an administrative receiver whereas traditional financing methods, including the sale and leaseback and bank loan structures above, will rely on an administrator (who has a duty to all creditors) to sort things out if they go wrong. Securitisation may retain an edge over the alternatives as a result.

\section{CONCLUSION}

Pub securitisation is here to stay. The structures that already exist include long-term fixed-rate debt that is extremely costly to redeem, and hence should run a long way through their tenor. It is highly likely that existing structures will be used to issue new debt by way of tap issues which will maintain leverage within a given structure. New assets will continue to be added as the sector consolidates further. There are few large leased portfolios left that have not been securitised, and hence brand new transactions are likely to be few and far between. Floating-rate notes will continue to be refinanced, and at some point the existing transactions will have amortised sufficient debt to justify releveraging, especially if they have delivered EBITDA growth.

Extension to managed pubs will depend on the attractiveness of alternative sources of finance. If Mitchells \& Butlers remains independent, a transaction should be seen soon. But the aims of a listed plc (namely, sensible long-term financing that offers sufficient flexibility for management, and the ability to make the dividend payments required by shareholders) differ from those of a financial buyer aiming to maximise leverage. Portfolios that are in the hands of financial buyers, such as Laurel, have not found the securitisation route as attractive as other methods. It could be that the announcement of Mitchells \& Butlers is a false dawn in managed pub securitisation. The acid test may be Scottish \& Newcastle Retail, depending on the ultimate buyer, and what happens to its constituent parts. The author's guess is that some will be securitised and some will be financed by other means.

(C) Fitch Ratings Limited 